\title{
INTERCALATING LAW AS A TOOL TO PROMOTE ECONOMIC EFFICIENCY IN INDONESIA
}

\author{
Fajar Sugianto \\ Tomy Michael Saragih \\ Fakultas Hukum Untag 1945 Surabaya \\ Semolowaru 17 Surabaya \\ Email: dr.fajarsugianto@yahoo.com; a_los_tesalonicenses@yahoo.com
}

\begin{abstract}
Indonesia as a Rechtsstaat like any other developing countries, its society is based on patterns and economic classes, overall obedience to the law is not easy. In heterogeneous society formed of groups based on religion, race, language, and wealth, it is one of the most difficult unifying factors in terms of compliance with the law. Conflict of interest tend to make any law may be resisted. As a consequence being a Rechtsstaat, the greatest difficulty is to produce efficient legal outcomes and consistency of legal practice. At this point, the law and economics offers economic efficiency as a framework to model effective legal outcome and common purposes to widely unify disparate areas of legal activities. The primacy of efficiency helps to harmonise the practice of law with social practices. When such law exists, it does function as a social tool aiming at the promotion of economic efficiency that goes well with other social practices. Efficiency in law simplifies how law works in different society, especially in heterogeneous communities. This approach does not reduce law to economics (or vice versa, for that matter), it claims simply that law and economics have a lot to learn from one another.
\end{abstract}

Key words: economic efficiency, consistent legal practices, law and economics

\begin{abstract}
Abstrak
Indonesia sebagai Rechtsstaat, seperti negara berkembang lainnya, masyarakatnya didasarkan pada susunan tatanan dan kelas ekonomi, ketaatan hukum secara keseluruhan adalah tidak mudah. Dalam masyarakat heterogen yang terbentuk dari berbagai macam kelompok berdasarkan agama, ras, bahasa, dan tingkat kekayaan, hal-hal semacam ini menjadi salah satu faktor pemersatu yang sulit dalam hal membentuk ketaatan hukum. Konflik kepentingan cenderung membuat hukum apapun ditentang. Sebagai akibat dari bentuk negara hukum, kesulitan terbesar adalah menghasilkan hukum yang efisien dan menciptakan konsistensi praktek hukum. Pada titik ini, Hukum dan Ekonomi menawarkan efisiensi ekonomi sebagai kerangka kerja untuk model hasil hukum yang efektif dan tujuan umum untuk menyatukan disparitas praktek hukum. Keunggulan efisiensi membantu untuk menyelaraskan praktek hukum dengan praktek-praktek sosial lainnya. Ketika hukum seperti ini ada, ia berfungsi sebagai alat sosial yang membuat hukum berjalan seiring senada dengan praktek-praktek sosial lainnya. Efisiensi dalam hukum menyederhanakan bagaimana hukum bekerja dalam masyarakat yang berbeda, khususnya pada tatanan masyarakat yang heterogen. Pendekatan semacam ini tidak mengurangi keberadaan hukum terhadap ekonomi (atau sebaliknya, dalam hal ini), hanya menegaskan bahwa hukum dan ekonomi harus saling mengisi.
\end{abstract}

Kata kunci: efisiensi ekonomi, praktek hukum yang konsisten, hukum dan ekonomi 


\section{Introduction}

Indonesia as a Rechtsstaat seems to be having typical difficulties in legal practice both in attaining justice (justitia) and enforcing the rule of law (veritas) at the same time. As a consequence being a Rechtsstaat, the greatest difficulty is to produce efficient legal outcomes and consistency of legal practice.

In general, a Rechtsstaat guarantees equality before the law as well as providing equal protection, protects individual rights and upholds sovereignty. According to the Constitution of the Republic of Indonesia (Undang-Undang Dasar 1945), Indonesia must be able to produce these two legal outcomes together, that is in dispensing justice and providing legal certainties. As a result, this ideology of the Constitution cannot be realised and had produced greater impacts to the law. The efficacy of law transforms into a legal "menu" that provides alternatives and varieties to choose from according to people's preferences. Legal practitioners seem to have plenty of choices, when to choose the rule of law and when to elect justice. In terms of obeying the law, it seems to offer some sort of freedom in understanding the law, when to interpret them dogmatically, when to identify them with theoretical perspectives, and when to build up philosophical analysis. Even in forming legal reasoning and organising legal standing, the law seems to justify the sacrifices of principles, such as: morality, but on the other hand, there will be times to ask for it. These indicate that law is no longer functioning in subjecting human behaviour. Furthermore, these also show disparity in legal practice which encourages inconsistency. At this point, the law and economics offers economic efficiency as a framework to model effective legal outcome and common purposes to widely unify disparate areas of legal activities. By some token, the primacy of efficiency helps to harmonise the practice of law with social practices. When such law exists, it does function as a social tool aiming at the promotion of economic efficiency that goes well with other social practices. To understand this concept, it is important to view some dimensions of law in Indonesia as systems and methods that commonly practiced.

\section{Consideration}

\section{A. Existing System}

\section{National law}

National law refers as a set of rules that govern the patterns of behaviour in a given society. Beyond this, however, there are serious conditions after reformation era as a new era in regulatory reform in Indonesia. Although the aim of reformation since late 1990's was mainly to promote and speed-up democratisation, reformation resulted in hyper-regulated, overlapping, contradicting, inconsistent, unsynchronised and inharmonious, sectoral, and creating multi-interpretation in laws. According to Supancana, hyper-regulated or overregulated 
can be seen in the fact that at national level only. The number of regulations covering from constitution, laws, government regulations, and presidential regulations have reached almost 20.000 regulations. This number excluded regulations at ministerial or sect oral level. The number of regulations from 33 provincial governments and 491 regency/ mayoralty reached about 18.000 regulations and still growing. He also emphasises that in many occasions, those regulations are overlapping. Sometimes the similar issues are regulated by many different regulations. This may be caused from unclear division of main functions of governmental institutions and also conflict of interest. Contradiction among regulations also happen both vertically (between central and local regulations) and horizontally (between sectors). He concluded that these create inconsistencies which derive inharmonious and unsynchronised conditions ${ }^{1}$.

At present times, Indonesia is starting to understand the necessities in planning strategic actions in the legal context in order to achieve economic success that the country can establish predictable and stable legal regimes. This effort can be seen from the actualisation of statutory laws such as the Law of the Republic of Indonesia Number 12 year of 2011 concerning the Formation of Statutes (Undang-Undang Nomor 12 Tahun 2011 tentang Pembentukan Peraturan Perundang-
Undangan), which stated basic principles in regulating the rule of law. Namely: clarity of purpose; institutional or accurate forming institutions; correspondence between forms and content material; executable; efficiency and utility; clarity of formulation; impartiality.

Other principles like transparency, accountability, and equity are importantly outlined in formulating and performing the law of the Republic of Indonesia Number 40 year of 2007 concerning Limited Company. This due to the increase role of business entities both nationally and internationally in promoting economic growth and development in Indonesia, resulted from the globalisation insistence that requires the performance of good governance.

Still looking at Indonesia's attempt in achieving economic success through the eradication of corruption. The principle of legal certainty, proportionality and public interest are employed in the law of Republic of Indonesia Number 20 year of 2001 (Undang-Undang Republik Indonesia Nomor 20 Tahun 2001). To support this, a special commission (Komisi Pemberantasan Korupsi - Corruption Eradication Commission) had been established with extensive authority which stipulated in the law of Republic Indonesia Number 30 year of 2002.

Furthermore, in terms of economic performance at regions, the law of district autonomy has been established mainly

1 I.B.R Supancana, Berbagai Perspektif Harmonisasi Hukum Nasional dan Hukum Internasional, Universitas Atma Jaya, Jakarta, 2012, p. 1-4. 
regulates on how to pass or carry out regulations in conducting good governance with basic principles, namely: terminology clarity, recognisable, equality, legal certainty, and law enforcement.

These realisations show that economics principles can be used to law by simply asking what effects do laws have? And given the effects of laws, which are socially best? Such questions about the influence and desirability of laws have been investigated by legal scholars and economists in a new, rigorous, and systematic manner since the 1970s. Their approach, called economic, is widely considered to be intellectually compelling and to have revolutionised thinking about the law ${ }^{2}$.

Law and economics radically transformed legal thinking. Traditional forms of legal practitioners were mostly backwardlooking. One reasoned from "legal menu" to decide present disputes, seemingly without much concern (at least explicitly) for the effect today's decision would have on future behaviour. Yet, law is necessarily forwardlooking. To be sure, a major function of our legal system is to resolve present disputes, but law's principal function is to regulate future behaviour. The law and economics movement succeeded because it recognised that legal practitioners cannot administer justitia or veritas solely retrospectively. They must also consider what rules their decisions will create to guide the behaviour of other actors in the future. The genius of law and economics was giving judges a systematic mechanism for predicting how rules will affect behaviour. Moreover, Law and economics is a branch of jurisprudence that aims to frame legal questions in terms of economic efficiency. While some maintain that legal questions can purely be reduced to economic ones, the more conservative stance that economics can describe at least part of the legal question.

\section{Customary law}

With the total area of $1,904,569$ square kilometres, Indonesia consists of 34 provinces with population of over $248,000,000$ people. Across its many islands, it also consists of hundreds of ethnic groups, mainly: Javanese 40.6\%, Sundanese 15\%, Madurese 3.3\%, Minangkabau 2.7\%, Betawi 2.4\%, Bugis $2.4 \%$, Banten $2 \%$, Banjar $1.7 \%$, other or unspecified 29.9\% (2000 census). These ethnic groups have their own customary practices (adatrecht) which are recognised and protected by the law. When it comes to a change through the law, it is difficult to achieve where desired change would come into conflict with customary practices, more so when they have religious or deep rooted social significance $^{3}$. So far, no establishment ever be made (and probably never will) to appoint which ethnic groups is credible enough to be a national standard in terms of formulating the law to subject Indonesians in general.

2 Steven Shavell, Foundations of Economic Analysis of Law, Belknap Harvard, Mass, 2004.

3 Burton Wright and John Weiss, Social Problems, Little Brown and Company, Boston, 1980, p.8. 
For Dayak tribe (Borneo island aborigines), it is their custom to host and held gambling not only during traditional ceremonies but also gambling became daily errand, while national law (and probably most laws) aim at controlling gambling as it considers to be unlawful act. For most Papuans, the law however failed to influence their attitude to liquor consumptions because consuming alcohol is considered legal according to the Papuans customary law.

Another difficulty is found when these ethnic groups show various psychological factors, that is habit. There is an old saying: "Habits die hard", and habits often act as resistant to change whether a law is morally good or whether it promotes social welfare. In this case, habits may not only have the effect of preventing a legal measure but delaying effect. This is ignorance, because they have traditional beliefs, and their social values are often differ from one ethnic to another. When a national law limits long-established practices or behaviours, certain groups that feels threaten will likely disfavour such a law. It can be said that ignorance and obedience to the laws may look the same for them as long as not breaking national laws.

\section{Islamic law}

Indonesia is the home to the world's largest Muslim population with total of $86.1 \%$ population (2000 census). This makes Islamic law in most occasions play a major role both in regulating and implementing the law.

According to Kamali, law in the Islamic legal order is part of a wider normative system-Shariah which refers to commands, prohibitions, guidance and principles that God has addresses to mankind pertaining to their conduct in this world and in the next. The rules of Shariah mainly consist of two categories: ibadat (devotional matters) and muamalat (civil transactions). The first category basically consists of fundamental rules which subjecting human to the relationship with the Creator, whereas the second is concerned with relations between man and his fellow human beings ${ }^{4}$.

Out of the general body of Shariah have been derived a large number of rules in respond to human needs, social progress, and change. The rules have their source in ijma (consensus of opinion among jurist) ${ }^{5}$. The bulk of the Islamic law has been built up by the exercise of ijtihad (juristic interpretation and construction) which have to be in consonance with the Quran, the Sunnah, and supported by ijma. ${ }^{6}$

The nature of Islamic law shaped majority of Indonesians (or probably for most Muslims) how they see a "law". Although the main objective of both Islamic law and national law is generally to regulate and subjecting human

4 Muhammad Hasim Kamali, Source, Nature and Objectives of Shariah, The Islamic Quarterly, Volume XXXIII, Number 4, 1988, p. 215.

5 Ibid., p. 219.

6 Muhammad Hashim Kamali, Shariah and the Challenge of Modernity', Jurnal JKIM, Volume 2, 994, p. 3. 
behaviour, there are significant differences between the two. According to Hamid, distinction between Islamic law and human law ${ }^{7}$ :

a. Islamic law derives its sources, authority and validity from the Quran which embodies the instructions and commandments of God, and the Sunnah, which consists of divinely inspired acts and teachings of the Prophet. Human law is laid down, or recognised, by an individual or a group of individuals in who lies for the time being the political power in society. Non-Islamic law and legal systems, are thus the creation of human will.

b. Islamic law to the extent it is contained in the Quran and the Sunnah, is permanent and unchangeable. Human law is changeable, and is changed by an individual or a group of individuals in whom the political power is for the time being vested.

c. Islamic law, which in its pure form is divine law, is distinct from human law in that it has its own ethical norms of good and bad, right and wrong, virtue and vice. In many cases what is regarded as good by a human law may be regarded an evil in Islamic law. For example, sexual relationship between two unmarried persons is not allowed by Islamic law though non-Islamic legal systems permit them as part of individual freedom. d. The sanction behind human law is the threat of punishment, which may vary in degree and form from one society to another. Islamic law imposes an additional sanction for disobedience to law. To obey the law is part of faith and religious duty. A Muslim will accountable before God on the Day of Judgement for his acts and omissions.

\section{Duty to obey the existing systems}

The issue of obedience may be brought from two of the most influential theorists, that is to say Legal Positivism and Dworkin's Law as Integrity. Austin ${ }^{8}$ argued that we obey the law because we fear we will be punished. He emphasised that law is what is commanded by the sovereign authority in the society and that the commands are backed by the ever present threat of sanctions.

It is true that an oppressive regime might secure obedience to its dictates by creating conditions of terror in which fear becomes the foremost reason for obeying the law. But in democratic societies like in Indonesia, the legal and political systems are founded on defined constitutional principles and the source of law is traceable in legitimate authority. Weber ads that there are limitations on the coercive power of law. The desire to avoid legal coercion is but one of many motives for law-abiding behaviour, one that

7 Abdul Hamid, The Islamic Theory of International Relations: New Directions for Islamic Methodology, International Institute of Islamic Thought, Herndon, 1987, p. 55-57.

8 John Austin, Lectures on Jurisprudence, John Murray, London, 1832. 
increases the probability of conformity but does not guarantee it $^{9}$. However, it is not always the fear that motivates people to obey the law. One may view the system and its function quite differently from others, dictated by his preferences. There are factors that limit the compliance with law, such as social factors, psychological factors, and cultural factors which are briefly considered earlier. At most, such laws in Indonesia allow lawmakers to predict that certain forms of behaviour will conform to the requirements of legal rules.

Another view is that law has essential moral content, a duty to obey the law. Moral and social rules, though less explicit and less formal in their nature and content, also play a significant role in society's efforts to force them to follow a certain course of conduct. One reason for obedience to law at this point is the respect of people in a society whose submit themselves to legitimate authority. Having this said that this kind of obedience motivates most individuals accept the law has the right to regulate behaviour and should be obeyed. That is why this type of viewers desire the law must come from the people to the people, thus the law earns respect for its social status and it is obeyed because it is the people's law.

Indonesia like any other developing countries, its society is based on patterns and economic classes, overall obedience to the law is not easy. In heterogeneous society formed of groups based on religion, race, language, and wealth, it is one of the most difficult unifying factors in terms of compliance with the law. Conflict of interest tend to make any law may be resisted.

In terms of obeying the Islamic law, there are few fundamental duties on which Islam is founded:

a. The belief in one God-the belief that God alone is the Creator, Ruler, Controller and Sustainer of all that exists ${ }^{10}$. The universe exists and functions because God so wills. God exercises power on this earth over those whom $\mathrm{He}$ has created in it. He alone is Sovereign and the Master of man's destiny. Only He can guide man through the course of life and instruct him regarding what is good and evil. God is the ultimate Law-Giver, and man can make law only subject to the Supreme Law of God. ${ }^{11}$

b. Prophet Muhammad is the last of the messengers sent by God to mankind. God's message took two forms: the Quran and the Sunnah. ${ }^{12}$

c. The belief in the hereafter (Akhirah). The time is fixed by God. Everyone on the Day of Judgement will be called upon to render a complete account of his or her acts and omissions. ${ }^{13}$

9 Max Weber, Law in Economy and Society, Max Rheinstein (Ed.), Cambridge, Harvard University Press, 1954.

10 Quran; $6: 73 ; 13: 16 ; 20: 8 ; 7: 54 ; 32: 5 ; 2: 107 ; 25: 2$.

11 Ibid., 35:3; 60:58; 6:164.

12 Ibid., 42:13; 15:9; 85:21-22; 3:84; 98:1-2; 53:2-4.

13 Ibid., 19:85-86. 


\section{B. Existing Functions}

\section{Law as a method of conflict resolution}

Societies evolve, they experience change and grow. They create policies, rules, even ethics/culture that continuously develop and change. Some groups of society tend to change more rapidly than those who likely more primitive and traditional. National law in primitive and simple societies (such societies have in fact existed and exist now), may be taken to refer entirely different things when compared to law in a modern society. Most likely they organise their life in compliance with their rules which are simple, easily identifiable, and their limited understanding of justice. For instance something is legal only if it is just, therefore, something is not law if it is unjust. On the other hand, communities in a modern society do not merely follow the fixed routines of the past but have goals toward which they strive, and they intend to accept diversity.

If there is social life, there will be conflict. Indonesian heterogeneous societies, like any other societies in any other countries are complex. Law deals with complex social, and conflicting societies apply law as a powerful instrument of regulation and control. In fact, law acts as an independent agent to facilitate their complexity. They belief in the capacity of law as a method of conflict resolution.

In terms of conflict resolution, law performs some functions: a. Law provides legal means by which all forms of conflicts must be settled by providing legal procedures that regulate the ways in which rights and liabilities can be protected and imposed by officials to conclude claims of the conflicting parties.

b. The judicial systems are backed-up by enforcement machineries that enable parties to create binding orders and binding force of law.

c. Law creates protections that encourage parties to enter into interactions in reliance of law's ability to defend their interests.

d. Law creates legal effect that breaches and unlawful act will be enforced or compensated.

e. By settling a dispute, law prevents future disputes from arising and inhibits further unregulated conflicts.

f. (National and Islamic) law can be transformed into an independent agent which facilitate and integrate the nature of problems.

g. The availability of (legal) institutions for dispute settlement decreases the use of unlawful force/violent between conflicting parties, such as duelling, feuding, thuggery, and public shaming.

\section{Law as a mechanism of social control}

The Constitution of the Republic of Indonesia guarantees equal protection of the laws. It also claims its power to provide proper relationship between government and its 
citizens. It has been said that the Constitution is tailored to the particular circumstances of different communities, as it will serve better the purpose for which it was designed, that is, to serve the common good. As the supreme law, it confers fundamental principles that contain mechanism of power control for the protection of the interests and liberties of the citizens.

Controls become increasingly important as groups of society are created on the basis of professions, values, ideologies and other distinctive characteristics. In order to establish social control, the Constitution protects human right (Chapter XA). For instance, Article 28J organises social control as:

Article 28J:

i. Every person shall have the duty to respect the human rights of others in the orderly life of the community, nation and state.

ii. In exercising his/her rights and freedoms, every person shall have the duty to accept the restrictions established by law for the sole purposes of guaranteeing the recognition and respect of the rights and freedoms of others and of satisfying just demands based upon considerations of morality, religious values, security and public order in a democratic society.

Furthermore, Article 28E regulates:

(1) Every person shall be free to choose and to practice the religion of his/her choice, to choose one's education, to choose one's employment, to choose one's citizenship, and to choose one's place of residence within the state territory, to leave it and to subsequently return to it.

(2) Every person shall have the right to the freedom to believe his/her faith, and to express his/her views and thoughts, in accordance with his/her conscience.

(3) Every person shall have the right to the freedom to associate, to assemble and to express opinions.

4. Article $28 \mathrm{H}$ :

(5) Every person shall have the right to live in physical and spiritual prosperity, to have a home and to enjoy a good and healthy environment, and shall have the right to obtain medical care.

(6) Every person shall have the right to receive facilitation and special treatment to have the same opportunity and benefit in order to achieve equality and fairness.

(7) Every person shall have the right to social security in order to develop oneself fully as a dignified human being.

(8) Every person shall have the right to own personal property, and such property may not be unjustly held possession of by any party.

Another some fundamental principles are governed in Chapter I that declares form of the state and sovereignty, Chapter $\mathrm{X}$ that protects citizens and residents rights, Chapter XIII about education, and Chapter XIV that guarantees economy and social welfare. 
3. Law as an instrument of social change

Both of the Constitution and most ordinary Indonesian statutory laws aimed to achieve one common goal that is social welfare and national economy. The Constitution guarantees social welfare (Chapter XIV, Article 34):

(1) Impoverished persons and abandoned children shall be taken care of by the State.

(2) The state shall develop a system of social security for all of the people and shall empower the inadequate and underprivileged in society in accordance with human dignity.

(3) The state shall have the obligation to provide sufficient medical and public service facilities.

(4) Further provisions in relation to the implementation of this Article shall be regulated by law.

In order to fulfil these credible commitments, the Law of Republic of Indonesia Number 11 year of 2009 concerning on Social Welfare clearly defines social welfare as the fulfilment of conditions of material, spiritual and social needs of citizens in order to live well and be able to develop themselves so that they can perform their social function. The state is fully committed to be responsible for the implementation of social welfare which aiming at: improving the level of social welfare, quality, and survival; restoring social functions in order to achieve self-sufficiency; improving social resilience in preventing and dealing with social welfare; increasing the capacity, interests, and social responsibilities institutionally and socially sustainable; increasing the capacity and public participation in the implementation of social; and improving the quality of management of social welfare ${ }^{14}$.

\section{Efficacy of the Primacy of Efficiency}

\section{The economic approach to law.}

Legal practitioners may tend to think of law as a means (solely) of securing legal certainty or dispensing justice, unaware that law also provides a complex structure of what economists would call "incentives" which promote what economists would call "efficiency". A perfect example of an efficiency improvement is where a firm produces harmful effluents that contribute to polluting the natural environment. A firm that releases harmful effluents can simply be prevented from doing so, thus likely leading to the closing of the firm. However, if the cost to society from, say, a ton of effluent can be accurately measured, the firm can be asked either to pay a price per ton of effluent equal to this cost or cease production. The firm can

14 Compare with Pigou's aim of welfare: To ascertain how far the free play of self-interest, acting under the existing legal system, tends to distribute the country's resources in the way most favorable to the production of a large national dividend, and how far it is feasible for State action to improve upon 'natural' tendencies. See Ronald H. Coase, The Problem of Social Cost, Journal of Law and Economics, Volume 3, The University of Chicago Press, Chicago, 1960, p. 29. 
then find a profit-maximising level of effluent production, and if profits are positive at this level, the new situation, with a lower level of effluent and a tax on the effluent, may be more efficient than either the original situation or simply closing down the firm ${ }^{15}$.

From Law and Economics point of view, law does not merely force people to follow a certain course of conduct or simply urge social change/control by its authority to act as a binding force, but it employs a variety of means of altering human behaviour. The basic assumption of economics, even in law activities that involves social interactions is that people are rational and forward looking. Meaning that people always demand and use any available resources to meet their needs. In fact, what we want exceeds with what available no matter how wealthy or poor we are as individuals or even as a nation. The people's infinite need of satisfaction is a predictable consequence of the gap between desirability and resources availability. The need to satisfy themselves often refers as profit maximisation in both non-monetary and or monetary satisfaction. This demand and need to maximise profit is an observable trait of human behaviour in economics, while law generally regulate and justify human behaviour to maximise society's wealth.
If lawmakers ask, "How will a sanction affect human behaviour?", then economists may consider legal sanctions look like prices. People presumably respond to these sanctions as much as they respond to prices. Economics in this case provides a scientific theory to predict the effects of legal sanctions on behaviour. Therefore, it can be said that economics provides a behavioural theory to predict how people respond to law. The use of this theory and its fundamental concepts help us to understand in evaluating law. The approach enables lawmakers to understand a broader domain of the law as the enterprise of subjecting human behaviour. If law indeed is the enterprise of subjecting human behaviour to the governance of rules, it is sine qua non of the successful working of law that people should have knowledge of law and should have confidence in $i^{16}$. How law can do its duty to achieve all its purposes without knowing an economic fact that the poor is ruled by a system which he neither understand nor trusts. In a country like ours which is governed by the rule of law, it is essential that the law must become community property to maximize overall social utility ${ }^{17}$. Posner describes such ability that law can provide is the economic conception of justice. In Indonesia, this conception can be blended equally

15 Ronald H. Coase, The Firm, The Market, and The Law, The University of Chicago Press, Chicago, 1988. 16 P.N. Bhagwati and M.J. Anthony, Law for the Layman, HPB, New Delhi, 2008, p. viii.

17 Wayne Morisson, Jurisprudence-from the Greeks to Post Modernity, reprinted and translated by Zhang Wan Hong, Cavendish Publishing, UK, 2002, p. 190. 
with the doctrine of the Rechtsstaat which protects individual rights as well as upholds sovereignty to provide social welfare ${ }^{18}$.

Having said this, economics plays a major role in creating and operating the law so that the law can actually distribute justice which becomes an economic standard. Of course the idea of justice according to most legal positivists differ from economics perspective, but again, the idea of economic justice help to bring clarity of purpose in legal practices.

The law and economics movement provides a general theory of law as well as conceptual tools for the clarification and improvement of its practices. The general theory is that law is best viewed as a social tool that promotes economic efficiency. With economic approach, efficiency is an ideal model that guides legal practice. Why? Because most people as homo economicus (except children and the profoundly retarded) in all of their activities have one thing in common, that is the need for efficiency, perhaps efficiency is the nearest we are likely to approach to a universal secular "religion". Efficiency in law simplifies how law works in different society, especially in heterogeneous communities. The concept of efficiency is outlined generally at the following section.

\section{Some fundamental concepts}

in order understand the compass of law as the enterprise of subjecting human behaviour
I shall employ some fundamental economics concepts which broaden the fields of law and behavioural economics. Namely: the concept of rationality, choice, value, efficiency, utility, and game theory.

The concept of rationality is the main framework analysis in understanding human behaviour. The basic assumption is people are rational maximizer of their satisfaction, their activities involve choice. They are able to calculate (based on their rationality) what to choose in order to achieve the best outcome and it can be said that these decisions to be rational. Because of most people are rational, and rationality requires maximisation, an economic actor can rank alternatives that become their next-best alternative choices.

Another common way of understanding this conception of rational behaviour is by recognising that people choose alternatives that are the most well- suited to fulfilling their needs. Here is another economic fact, most people want far more than their current resources allow them to have. This is scarcity: people wanting more than can be satisfied with available resources. Scarcity forces people to make the most valuable choices. This emphasises that had people not made the "right" choice they did, they would have then chosen the next best alternative. The definition of "right" choice is varying from one individual to another, again, based on their rationality and needs. Having said this, 
the right choices in economic activities are closely-related to the most valuable ends.

As rational maximizer, people tend to accomplish their objectives in the most efficient way. Economists have several distinct definitions of efficiency. For simplicity's sake, I have also adopted Pareto efficiency theory of economics which generally concerns the satisfaction of individual preferences as one of the most applied efficiency concept in the field of law and economics. Garner splits Pareto efficiency into two kinds, first kind is Pareto superiority as an economic situation in which an exchange can be made that benefits someone and injures no one. When such exchange can no longer be made, the situation becomes the second kind that is Pareto optimality: an economic situation in which no person can be made better off without making someone else worse off. ${ }^{19}$

There is a vital connection between efficiency and utility. Formosteconomic actors, utility reflects beneficiary and meritorious of economic goods. If a person believes that his act was successfully efficient, at the same time he/she concluded the result to be satisfactory. Again, a satisfactory result signifies both in monetary and or non-monetary outcome.

The utility concept is used in different sense for economists and for utilitarian. According to Posner, utility in economics is commonly used to distinguished an uncertain cost or benefit from a certain one. Utility also commonly called as an expected utility, in this sense is tangled with the concept of risk. Utility in the sense used by philosophers of utilitarianism, meaning happiness. ${ }^{20}$

Game theory basically is the study of how people behave in situations where one's action may affect the reaction of others. These situations are like games in that people must decide upon strategy. Game theory has far wider applications, some economics experts say to be the theory of coordination. Wessels describes that game theory extends the tools of economic analysis to any situation where humans have to coordinate their actions with one another, whether in the family, in the workplace, in social groups or among nations. He extends his view toward game theory that an important feature of game theory is that people are rational in making their choices (that is, their preferences are well ordered). A second key feature is that a person has to take into account the reaction of others. ${ }^{21}$ At this point, I trust that people need a dominant strategy that is a strategy better than other's strategy regardless of what the others in the game do. It drives people come to cooperate with each other in a positive-sum game.

By knowing these fundamental concepts help us to view the work of law. First, how rationality affects people's behaviour within legal situations. Second, how collective

19 Bryan A. Garner, Black Law Dictionary (8th edition), Thompson West Group, USA, 2004, p. 1147.

20 Richard A. Posner, Economic Analysis of Law (seventh edition), Aspen Publishers, New York, 2007, p. 1012.

21 Walter J. Wessels, Economics, Barron's Educational Series, USA, 2006, p. 440-441. 
behaviour should have an effect on legal rules. Third, understanding and planning strategic actions in the legal context.

\section{Law as a tool to promote economic efficiency}

$i$ advocate that law is best understood as a tool to promote economic efficiency. Once succeeded, it can be used to maintain Indonesia's economic growth and to achieve economic success as well as to establish social welfare. It is important for the law to define the core aspects of proper legal practice in economic performance in order to amplify the function of law and the nation's main objectives.

But, how can the institution (of law) encourage efficient transactions? Here are some examples. Note that legislative law is often inefficient. A free market in body parts is illegal in virtually every country around the world. This creates huge inefficiencies. For instance, thousands die each year waiting for kidney transplants from compatible donors, but it is illegal to buy a kidney from a healthy person who would love to sell it. Donor sperms and eggs are illegal to be used in IVF (In Vitro Fertilisation) treatment even for those who suffer from serious infertility problems that require more advance medical assistance. I am sure there are plenty of infertile married couple who would be willing to do almost anything to have a baby of their own, who most probably will value the presence of the baby, while there is too little effort from the law to deal with illegal abortion and unwanted birth. But these efficiency enhancing exchanges are forbidden by the law. If these issues were left to economic efficiency, such exchanges should be allowed, and I cannot see why law cannot accept an academic fact that (if law indeed a science), medical science in this case, provide scientific explanations the need for those who need medical treatment.

Laws in Indonesia need to promote economic efficiency in at least two ways: structure the law in order to remove impediments that encourage private bargaining which based on customary practices that promote economic efficiency; and structure the law to minimise the harm caused by failures in private bargaining (practices that discourage economic efficiency) ${ }^{22}$. When private bargaining fails, the laws should be allocated to those who value them the most. This is the efficacy of law as a tool to promote economic efficiency.

\section{Conclusion}

In recent times, Indonesian law students may find law and jurisprudence hard to articulate because of their scope of analysis range over many different subjects and lay on many other disciplines, such as sociology, politics, economics, and so on, which surprisingly be considered as having little to do with law and legal study. What comes harder is that there is still a group of legal

22 These models are also known as Normative Coase and Hobbes Theorem. 
scholars who believes that jurisprudence is the only key to solve legal problems. There are a number of practitioners and jurists who still believe that law has nothing to do with economics. As much as I desire the capability of law to solve its own problems with its own "key", it is too hard to deny that jurisprudence as social science, like any other sciences, is best identified and well-explained with the help from other disciplines which complemented to one another.
The movement of law and economics applies economic theory and method to the practice of law. It claims the tools of economic reasoning offer the best possibility for justified and consistent legal practices. It is one of the dominant theories of jurisprudence.

By some token, the primacy of efficiency helps to harmonise the practice of law between justitia and veritas. When such law exists, it does function as a social tool aiming at the promotion of economic efficiency that goes well with other social practices. This can be considered as law that fits Indonesia.

\section{REFERENCES}

\section{Books}

Abdul Hamid, 1987, The Islamic Theory of International Relations: New Directions for Islamic Methodology, International Institute of Islamic Thought, Herndon.

John Austin, 1832, Lectures on Jurisprudence, John Murray, London. P.N. Bhagwati, and M.J. Anthony, 2008, Law for the Layman, HPB, New Delhi.

Ronald H. Coase, 1988, The Firm, The

Market, and The Law, The University of Chicago Press, Chicago.

Bryan A .Garner, 2004, Black Law Dictionary

(8th edition), Thompson West Group, USA.

I.B.R Supancana, 2012, Berbagai Perspektif Harmonisasi Hukum Nasional dan Hukum Internasional, Universitas Atma Jaya, Jakarta.
Wayne Morisson, 2002, Jurisprudencefrom the Greeks to Post Modernity, reprinted and translated by Zhang Wan Hong, Cavendish Publishing, UK.

Richard A. Posner, 2007, Economic Analysis of Law (seventh edition), Aspen Publishers, New York.

Steven Shavell, 2004, Foundations of Economic Analysis of Law, Belknap Harvard, Mass.

Max Weber, 1954, Law in Economy and Society, Max Rheinstein (Ed.), Cambridge, Harvard University Press.

Walter J. Wessels, 2006, Economics, Barron's Educational Series, USA.

Burton Wright and John Weiss, 1980, Social Problems, Little Brown and Company, Boston. 


\section{Journals}

Ronald H. Coase, 1960, The Problem of Social Cost, Journal of Law and Economics, Volume 3, The University of Chicago Press, Chicago.

Muhammad Hashim Kamali, Shariah and the Challenge of Modernity', Jurnal JKIM, Volume 2, 994. 1988, Source, Nature and Objectives of Shariah, The Islamic Quarterly, Volume XXXIII, Number 4. The 1945 Constitution of the Republic of Indonesia. 